\title{
THE VALIDITY OF PROJECT-BASED LEARNING DEVICES ON MOMENTUM AND IMPULSE MATERIALS IN INCREASING STUDENTS' CREATIVITY
}

\author{
Farah Hulwani Lala Junti, Gunawan*, Ahmad Harjono, Ahmad Busyairi, and Kosim \\ Physic Study Department, FKIP University of Mataram, Mataram, Indonesia \\ *Email: gunawan@unram.ac.id
}

Accepted: November, 202021 Approved: November, 22 2021. Published: November, 222021

\begin{abstract}
This study aims to determine the validity of project-based learning devices to increase students' creativity on momentum and impulse materials. It is a research and development type with a 4D (Define, Design, Develop, and Disseminate) model developed by Thiagarajan. The validity of the product developed in this study was tested by 2 Physics education expert lecturers and 3 Physics teacher practitioners. This study indicates that the learning device is feasible to proceed to the operational trial phase in learning activities. Based on the assessment by the device validator, it obtained an average validity value of $86.72 \%$ with a very feasible category. The student responses to the developed device are positive, with an average value of $100 \%$.
\end{abstract}

Keywords: learning device, project-based learning, creativity, momentum, impulse.

\section{INTRODUCTION}

Physics is one of the subjects in the educational curriculum that requires teachers and students to be creative. In line with this, it is known that the purpose of Physics subjects is for students to have the ability to develop reasoning skills in inductive and deductive analytical thinking by using the concepts and principles. Physics explains various natural events and solves qualitative and quantitative problems [1]. However, the reality shows that the ability of students to explore their knowledge and reasoning skills is still low, which has an impact on the low creative thinking skills of students in solving Physics problems.

The low ability to think creatively occurs because students are not trained to use their skills and tend to be passive and not creative. Students are familiar with the learning system, such as listening to the teacher's explanation and doing practice questions based on the level of mere understanding. Therefore, learning is still teacher-centered. Students lack the opportunity to develop their way of thinking and vary their level of understanding in studying the material obtained during class learning [2]. It indirectly limits the scope of students in developing their creativity.

Creativity or creative thinking skills in the era of globalization are essential provisions in welcoming the industrial revolution 4.0. Physics, in essence, teaches knowledge (cognitive) and trains the attitudes and skills needed by students in overcoming various existing problems. Someone creative will find new ways to solve problems faced in everyday life [3]. However, Physics has been considered the science of formulas and issues all this time. Thus, to present fun learning for students, the learning process in the classroom must be conducted correctly and with good quality [4].

Improvement in the quality of education in Indonesia always follows the development of life in this century. Curriculum improvement from KTSP to Curriculum 2013 is one form of improvement that has been done [5], causing changes in learning activities and learning facilities such as learning devices. Learning devices are forms of teachers' preparation before teaching to learn and achieve competencies as expected. Therefore, teachers are required to design good learning by choosing the correct method according to the character of the material [6].

The learning process's selection of learning methods and models is also adjusted to the applied curriculum. The curriculum used as a reference in this study is Curriculum 2013. Through the interviewed students, it was found that they are happier when the teacher explains the material being studied. The students are only active on certain materials that they find interesting, while on less interesting material, students tend to be passive and prefer teachers to explain. Most of the teachers still pay less attention to students' thinking skills and the methods used are less varied. As a result, students' motivation and learning patterns tend to be memorizing and mechanistic [7]. Based on this opinion, a learning model that can foster a fun, memorable atmosphere still focuses on learning materials is needed. One of the learning models in the Curriculum 2013 that provides opportunities for students to be more active is the project-based learning model.

A project-based learning model is an innovative approach that emphasizes contextual learning through complex activities [8]. Through a project-based model, students are expected to be able to develop their creativity which is then implemented into the projects they work on. Projectbased learning models can encourage students to carry out investigations and work collaboratively in doing research, creating projects, applying their knowledge in discovering new things, proficiency in using technologies, and solving problems [9]. The problems studied are complex problems that require 
mastery of various concepts and principles to solve to produce a product.

The products made are obtained using the concepts and principles of Physics as outlined in creative ideas. It is in line with the opinion that creative thinking in learning Physics is the main goal in the educational process [10]. Without creativity, students will only work at a narrow cognitive level. Based on the results of an interview with one of the Physics teachers at one of the schools, SMAN 1 Praya, information was obtained that the projectbased learning model is still rarely used because it tends to be difficult to implement, especially in the matter of time. Therefore, learning devices that use project-based models are still limited to certain materials.

One learning material that requires students to be active in independent learning is momentum and impulse material. However, project-based learning is still rarely applied to these two materials due to time constraints, so teachers prefer to deliver this material conventionally. Based on the results of previous studies, it is known that the Project-Based Learning model on the subject matter of environmental pollution can increase the creativity of students during the implementation of learning [11]. Students' creative thinking skills become trained by participating in project-based learning [12]. Based on the description above, it is necessary to develop project-based learning model learning devices to increase students' creativity following the educational conditions of the pandemic era.

\section{RESEARCH METHODS}

The type of research used in this study is Research and Development with a 4D development model (Define, Design, Develop, and Disseminate) developed by Thiagarajan [13]. The product developed is a project-based learning device for momentum and impulse material in increasing students' creativity.

a. Design Stage

At this stage, the researcher designed a draft of a project-based learning device and data collection instruments in validation sheets and student response sheets.

b. Development Stage

The development stage is the stage of developing a product that has been planned. The development stage is conducted through a feasibility test or product validity. Validators and students conduct the feasibility test. Expert validators, in this case, are lecturers of Physics education at the University of Mataram, and practitioner validators, i.e., high school teachers, and for students who fill out the response questionnaire are students of Physics education at Mataram University. Suggestions given by the validator and the results of student responses are used as a reference to improve learning devices so that the resulting product is suitable for use in learning activities.

c. Disseminate Stage

This stage aims at distributing learning device products.

\section{Data Collection Instrument}

The data collection technique to determine the feasibility of the learning device is the validity test. Data were collected using validation sheets and response sheets for Physics education students and data analysis using the following equation [1].

Note:

$$
P=\frac{f}{N} \times 100 \%
$$

$\mathrm{f}=$ score obtained

$\mathrm{N}=$ Number of Frequency/maximum score

$\mathrm{P}=$ Percentage

The scale used in this study is a rating scale with four choices in the questionnaire. Converting the results of adjectives into numbers as follows:

Table 1. Assessment Score Against Answer Choices

\begin{tabular}{lc}
\hline Answer Options & Score \\
\hline very good & 4 \\
good & 3 \\
pretty good & 2 \\
not good & 1 \\
\hline
\end{tabular}

The validation questionnaire and response use four choices according to the content of the question. The percentage data obtained is then converted into the eligibility criteria for learning devices listed in Table 2 below [14].

Tabel 2. Eligibility Criteria for Learning Media

\begin{tabular}{ll}
\hline Percentage & Eligibility Criteria \\
\hline $85,1 \%-100 \%$ & very eligible \\
$70,1 \%-85 \%$ & eligible \\
$50,1 \%-70 \%$ & pretty eligible \\
$1 \%-50 \%$ & less eligible \\
\hline
\end{tabular}

Student response analysis was conducted to determine their response to the learning device developed by the researcher. The percentage of student responses can be calculated by equation [15]. The criteria for the percentage results obtained can be seen in Table 3 .

Table 3. Response Calculation Results Category

\begin{tabular}{cc}
\hline Ranges & Category \\
\hline $81 \%-100 \%$ & very good \\
$61 \%-80 \%$ & good \\
$41 \%-60 \%$ & pretty good \\
$21 \%-40 \%$ & not good \\
$\leq 20 \%$ & bad \\
\hline
\end{tabular}




\section{RESULTS AND DISCUSSIONS}

The results of this study consist of the results of the 4D model research stages, i.e., the define stage, the design stage, the development stage, and the disseminate stage. In the initial analysis, there were various problems encountered, one of which was that the teacher had not given full attention to increasing students' creativity while studying Physics, especially the momentum and impulse material. It can be seen from the selection of the dominant learning model used in direct teaching before the COVID-19 outbreak. The emphasis on Physics which tends to only focus on mathematical equations, causes students to learn monotonously and less actively. One of the materials in Physics that is considered affected is momentum and impulse. Furthermore, identification was conducted on the concepts of the material being taught. After the initial analysis, the initial draft of the learning device was designed.

The results of this development were in the form of a learning device consisting of lesson plans, students' sheets, and creativity assessment instruments. The device was then tested for feasibility based on the assessment and advice of the expert and practitioner validators. The validator's assessment of the device in detail is as follows.

Table 4. Results of Lesson Plan Validation

\begin{tabular}{lcc}
\hline \multicolumn{1}{c}{ Criteria Assessed } & Percentage & Category \\
\hline Completeness of lesson plan identity & $100 \%$ & Very feasible \\
Contain KI 1 - KI 4 and KD. & $100 \%$ & Very feasible \\
Compatibility of KI with KD. & $96 \%$ & Very feasible \\
Indicator refers to KD. & $88 \%$ & Very feasible \\
The active verbs on learning objectives. & $88 \%$ & Very feasible \\
Suitability of indicators. & $75 \%$ & Feasible \\
Contains learning objectives. & $79 \%$ & Feasible \\
Contain the material (Facts, Concepts, and Procedures) & $88 \%$ & Very feasible \\
Compatibility between approaches, models, and learning methods & $79 \%$ & Feasible \\
Contain the media and the learning resources used & $83 \%$ & Feasible \\
Steps of learning activities already reflect the syntax of the project-based model & $88 \%$ & Very feasible \\
Activities at the beginning, core, and end of learning are displayed. & $79 \%$ & Feasible \\
Displays the time allocation for each learning stage. & $83 \%$ & Feasible \\
Suitability between methods, techniques, and forms of assessment instruments. & $71 \%$ & Feasible \\
Preparation has been systematic. & $88 \%$ & Very feasible \\
The use of standard language follows the grammatical rules & $92 \%$ & Very feasible \\
The average value of lesson plan validity & $85,93 \%$ & Very feasible \\
\hline
\end{tabular}

Table 5. Results of Students Worksheets Validation

\begin{tabular}{lcc}
\hline \multicolumn{1}{c}{ Criteria Assessed } & Percentage & Category \\
\hline contains cover, academic unit, class, time allocation, student identity, & $96 \%$ & Very feasible \\
objectives, and work instructions. & $79 \%$ & Feasible \\
Instructions for working are easy to understand & $83 \%$ & Feasible \\
suitability with the indicators presented & $75 \%$ & Feasible \\
already able to measure the achievement of learning objectives & $83 \%$ & Feasible \\
can develop students' creativity & $79 \%$ & Feasible \\
use of standard language and following grammatical rules & $75 \%$ & Feasible \\
attractive display design & $88 \%$ & Very feasible \\
contain examples of appropriate problem-related phenomena so that students & $82.29 \%$ & Feasible \\
can design and plan projects & \\
The average value of Students Worksheets &
\end{tabular}

Table 6. Results of Assessment Instrument

\begin{tabular}{lcc}
\hline \multicolumn{1}{c}{ Criteria Assessed } & Percentage & Category \\
\hline contains a student identity column & $100 \%$ & Very feasible \\
clearly and in-detail has written observation working instruction & $92 \%$ & Very feasible \\
& $88 \%$ & Very feasible \\
easy-to-use appraisal observation sheet in improving creativity & $92 \%$ & Very feasible
\end{tabular}


indicators contained in the observation sheet cover all aspects that support the implementation of the project-based learning model

83\% Feasible

$88 \% \quad$ Very feasible

$96 \% \quad$ Very feasible

92\% Very feasible

$91.15 \% \quad$ Very feasible easy-to-understand language

language use follows the grammatical rule

The average value of Rata-rata instrument assessment validity

Table 7. Syllabus Revision Results

\begin{tabular}{|c|c|c|}
\hline Validator & Comments and suggestions & Revision \\
\hline \multicolumn{3}{|c|}{ Expert Validator } \\
\hline Validator 1 & $\begin{array}{l}\text { Calculation of study time must be explicit and } \\
\text { adapted to project activities. }\end{array}$ & $\begin{array}{l}\text { - Adjusting time in learning activities with } \\
\text { project activities }\end{array}$ \\
\hline Validator 2 & - Repair skill indicator & - Repairing skill indicator \\
\hline \multicolumn{3}{|c|}{ Validator Praktisi } \\
\hline Validator 1 & $\begin{array}{l}\text { - The subject matter has not been contained (Facts, } \\
\text { Concepts, and Procedures) } \\
\text { - It is still integrating learning activities for the } \\
\text { knowledge component with the skills component. } \\
\text { - There is no knowledge and attitude component in } \\
\text { the assessment technique }\end{array}$ & $\begin{array}{l}\text { - Adding (Facts, Concepts, and Procedures) } \\
\text { to the material } \\
\text { - Separate learning activities for the } \\
\text { knowledge component and the skills } \\
\text { component } \\
\text { - Incorporating knowledge and attitude } \\
\text { components into assessment }\end{array}$ \\
\hline Validator 2 & Syllabus is good & - \\
\hline Validator 3 & Syllabus is good & - \\
\hline
\end{tabular}

Tabel 8. Lesson Plan Revision Results

\begin{tabular}{|c|c|c|}
\hline Validator & Comments and suggestions & Revision \\
\hline \multicolumn{3}{|c|}{ ExpertValidator } \\
\hline Validator 1 & $\begin{array}{l}\text { - Learning objectives are linked to the project model and } \\
\text { must contain elements of ABCD }\end{array}$ & $\begin{array}{l}\text { - Rewrite the learning objectives by } \\
\text { including ABCD elements and project } \\
\text { models }\end{array}$ \\
\hline Validator 2 & $\begin{array}{l}\text { - Assessment attachments (add cognitive assessments } \\
\text { and attach them at each meeting }\end{array}$ & $\begin{array}{l}\text { - Adding cognitive assessments and } \\
\text { attaching assessments to each meeting }\end{array}$ \\
\hline \multicolumn{3}{|c|}{ Practitioner Validator } \\
\hline Validator 1 & $\begin{array}{l}\text { - Learning outcomes assessment instruments appear at } \\
\text { every meeting }\end{array}$ & $\begin{array}{l}\text { - Adding the assessment of learning } \\
\text { outcomes) at each meeting }\end{array}$ \\
\hline Validator 2 & $\begin{array}{l}\text { Setting goals focuses on mastery of concepts, analysis } \\
\text { of phenomena, identification of events, design, and } \\
\text { creation of simple projects. }\end{array}$ & $\begin{array}{l}\text { Focusing goals on concept mastery, } \\
\text { phenomenon analysis, event } \\
\text { identification, and simple project } \\
\text { activities }\end{array}$ \\
\hline Validator 3 & The lesson plan is good & - \\
\hline
\end{tabular}

Tabel 9. Students Worksheet Revision Results

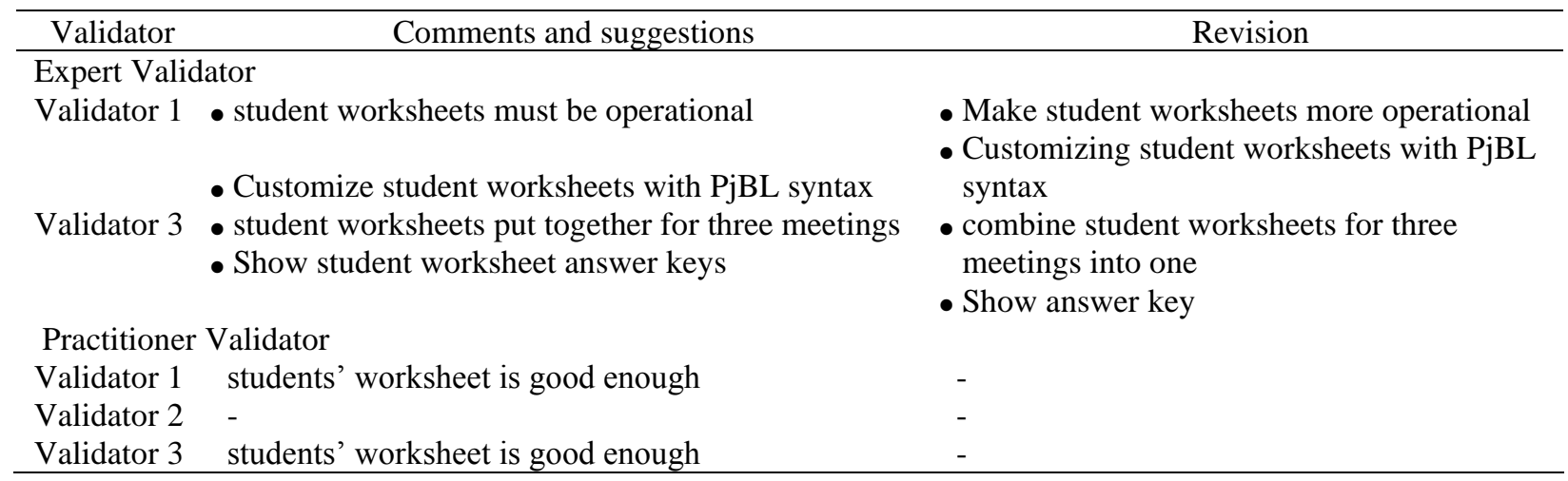


Tabel 10. Assessment Instrument Revision Results

\begin{tabular}{lll}
\hline \multicolumn{2}{c}{ Validator } & \multicolumn{1}{c}{ Comments and suggestions } \\
\hline \multicolumn{2}{c}{ Expert Validator } \\
Validator 1 & The instrument is good enough & - \\
Validator 2 & - & - \\
Validator 3 & Need more improvement on instruction & Adding more instruction \\
Practitioner Validator & \\
Validator 1 & - & - \\
Validator 2 & The instrument is good enough & - \\
Validator 3 & - & - \\
\hline
\end{tabular}

Based on the analysis of the validity of the learning device by the validator, it was found that the syllabus, lesson plans, and creativity observation instruments had a validity percentage of $87.50 \%$, $85.93 \%$ and $91.15 \%$ with an overall above $85 \%$ where these values were in very valid criteria [14]. This criterion represents that the developed learning device product is feasible for use in learning. Meanwhile, the validity of student worksheets is $82.29 \%$, where the value is in the valid and feasible criteria to use but requires some improvements.

Then, the improvements made to the learning device are made based on comments and suggestions from expert validators and practitioner validators for the progress of the developed tools. In detail, the following are suggestions and improvements obtained from expert validators and practitioners as follows.

Student response questionnaires were used as a consideration of whether the device made is feasible to use. Based on the student response data obtained, it is known that the device that has been developed has received a positive response from Physics education students. The syllabus developed in this study refers to the 2013 revised curriculum syllabus in 2017 then adapted to a project-based learning model and learning objectives to increase students' creativity. The syllabus developed to obtain an average validity value from expert validators and practitioner validators is $87.50 \%$ with very valid criteria. It means that the syllabus has met the basic principles of syllabus development, namely scientific, relevant, systematic, consistent, adequate, actual and contextual, flexible, and comprehensive [16].

The lesson plan was developed from the syllabus to lead learning activities to achieve Basic Competence $(K D)$. The feasibility of the lesson plan was evaluated from the value of the feasibility by the validator's assessment. Based on the validation results, the average percentage of lesson plan validity is $85.3 \%$, with very valid criteria. The validation results show that the lesson plan compiled contains important components in writing lesson plan based on Regulation of the Minister of Education and Culture Number 59 of 2014. Identity, core competencies $(K I)$, essential competencies $(K D)$, competency achievement indicators (GPA), descriptions of learning materials, learning activities, as well as media/devices, materials, and learning resources.

The lesson plan developed contains the syntax of a project-based learning model in the core learning activities. The project-based learning model requires skills by using the principle of learning by doing [17]. However, in an effort to improve the lesson plan that had been developed, it needed to be improved based on comments and suggestions from the validators. Improvements were generally aimed at formulating learning objectives that should contain elements of ABCD. Improve learning steps (especially in core activities that must have $\mathrm{PjBL}$ syntax), add cognitive assessments at each meeting, and focus on mastery of concepts, analysis of phenomena, identification of events, design and simple project creation. Based on the validity test results, it can be concluded that the lesson plan that had been developed is feasible to use in learning activities at school.

Student Worksheet is one of the learning media. The use of student worksheets aims to determine understanding of concepts, train students' skills, as practical instructions, as learning guides and help students apply and integrate some of the concepts that have been found [18]. Student worksheets as learning media can create good interactions between teachers and students so that learning activities can be more effective. The validity tests were conducted, and the average percentage of student worksheets was $82.29 \%$ with valid criteria. The developed student worksheets have met the criteria for preparing student worksheets based on the Ministry of National Education of 2008b, which states that student worksheets must contain at least: title, basic competencies to be achieved, completion, devices/materials needed to complete assignments, brief information, work steps, tasks to be done, and reports to be done.

The learning process using a project-based learning model aims to increase students' creativity. The development or increase in students' creativity is necessary to evaluate. The evaluation media used is creativity observation sheets which include creativity indicators, such as thinking original, flexible, fluent, and detailed [19]. The validation 
results show that the average percentage of lesson plan validity is $91.15 \%$, a very valid criterion.

The average assessment obtained on the feasibility test of the syllabus, lesson plans, student worksheets, and creativity assessment instruments, the percentage of validator assessments is $87,71 \%$. It is known that if the total average value of the validity of a learning media product is $\mathrm{P} \geq 85 \%$, the learning device is said to be very feasible that can be applied to increase students' creativity [20].

\section{CONCLUSION}

Based on the discussion above, it can be concluded that the feasibility of a project-based learning device has been completed with a percentage value of expert and practitioner validators of $87.31 \%$ and the results of student responses are positive responses with an average of $100 \%$. Based on the feasibility analysis of the results of the validator's assessment and the assessment of student responses, project-based learning tools that are very feasible are used as alternative learning tools that can be applied to increase students' creativity.

\section{REFERENCES}

[1] Liliawati, W \& Puspita, E. 2010. Efektivitas Pembelajaran Berbasis Masalah Dalam Meningkatkan Keterampilan Berfikir Kreatif Siswa. Prosiding Seminar Nasional Fisika 2010. Universitas Pendidikan Indonesia. Bandung: Tidak Diterbitkan.

[2] Umamah, C., \& Andi, H J. 2019. Pengaruh Model Project Based Learning Terhadap Keterampilan Berpikir Kreatif dalam Pembelajaran Fisika Terapan. Jurnal Penelitian Pembelajaran Fisika. 10(1): 71-76.

[3] Aktamis, H. \& Omer E. (2008). The Effect of scientific process skills education on students' scientific creativity, science attitudes and cademic achievements. Asia Pacific Forum on Science Learning and Teaching, Volume 9, Issue 1, Article 4, p.1.

[4] Jagantara, I M W, Adyana, \& Widiyanti. 2014. Pengaruh Model Pembelajaran Berbasis Proyek Terhadap Hasil Belajar Biologi Ditinjau dari Gaya Belajar Siswa SMA. Jurnal Program Pascasarjana Undiksha, 4(1): 1-13.

[5] Kusumaningrum, S., \& Djukri, D. 2016. Pengembangan Perangkat Pembelajaran Model Project Based Learning (PjBL) Untuk Meningkatkan Keterampilan Proses Sains dan Kreativitas. Jurnal Inovasi Pendidikan IPA, 2 (2): 241-251.

[6] Prasetyo, Z. K., et.al. (2011). Pengembangan Perangkat Pembelajaran Sains Terpadu untuk Meningkatkan Kognitif, Keterampilan Proses, Kreativitas serta Menerapkan Konsep Ilmiah Siswa SMP. Program Pascasarjana Universitas Negeri Yogyakarta.
[7] Wididiharto, R. 2004. Model-model Pembelajaran Matematika SMP. Yogyakarta: PPPG Matematika.

[8] Punomo, E A., \& Rohman, A. 2015. Pengembangan Perangkat Pembelajaran Project Based Learning ( $\mathrm{Pbl}$ ) Berbasis Maple Matakuliah Kalkulus Lanjut II. The 2nd University Research Coloquium 2015 ISSN 2407-9189: 164-172.

[9] Fathurrohman, M dan Sulistyorini. 2018. Belajar dan Pembelajaran: Meningkatkan Mutu Pembelajaran Sesuai Standar Nasional. Yogyakarta: Kalimedia.

[10] Armandita, P., Wijayanto, E., Rofiatus, L., \& Susanti, A. 2017. Analisis Kemampuan BerfikirKreatif Pembelajaran Fisika di Kelas XI MIPA 3 SMA Negeri 11 Kota Jambi. JUrnal Penelitian Ilmu Pendidikan, 10(2): 130.

[11] Lubis, F. 2018. Upaya Peningkatan Kreativitas Siswa Melalui Model Project Based Learning. Jurnal PeTeKa (Jurnal Penelitian Tindakan Kelas dan Pengembangan Pembelajaran). 1(3):192-201.

[12] Rohana, R S., \& Wahyudin, D. 2016. Project Based Learning Untuk Meningkatkan Berfikir Kreatif Siswa SD Pada Materi Makanan Dan Kesehatan. Jurnal Penelitian Pendidikan LPPM UPI. 16(3): 242.

[13] Sugiono. (2013). Metode Penelitian Kuantitatif Kualitatif Dan $R$ \&. D. Bandung : Alfabeta

[14] Akbar, S. 2013. Instrumen Perangkat Pembalajaran. Bandung: Remaja Rosdakarya Offset.

[15] Hobri. 2010. Metodologi Penelitian Pengembangan. Mangli: Pena Salsabila.

[16] Sahidu, C. 2017. Program Pembelajaran Fisika $(P 3 F)$. Mataram:Arga Puji Press.

[17] Sari, R T., \& Anggreni, S. 2018. Penerapan Model Project Based Learning (PjBL) Upaya Peningkatan Kreativitas Mahasiswa. Jurnal Varia Pendidikan. 30(1):79-83.

[18] Pratiwi, I A., Ardianti, S D, dan Kanzunnudin, M. 2018. Peningkatan Kemampuan Kerjasama Melalui Model Prject Based Learning (PjBL) Brbantuan Metode edutainment Pada Mata Pelajaran Ilmu Pengetahuan Sosial. Refleksi edukatik: Jurnal Ilmiah Kependidikan, 8(2).

[19] Munandar, U. 2009. Pengembangan Kreativitas Anak Berbakat. Jakarta: Rineka Cipta.

[20] Siwa, I. B., Muderawan, I W., \& Tika, I N. (2013). Pengaruh pembelajaran berbasis proyek dalam pembelajaran kimia terhadap keterampilan proses sains ditinjau dari gaya kognitif siswa. E-Journal Program Pascasarjana Universitas Pendidikan Ganesha, Vol 3(1): 1-13. 